\title{
Effect of growth regulators and stages of spray on seed yield and seed quality parameters of ridge gourd [Luffa acutangula $(\mathrm{Roxb}) \mathrm{L}$. .]
}

\author{
Sondarva Jyoti*, N. B. Patel and J. B. Patel \\ Department of Seed Science and Technology, College of Agriculture, Junagadh Agricultural University, Junagadh \\ -362001 (Gujarat), INDIA \\ *Corresponding author. E-mail: sondarvajyoti6568@gmail.com
}

Received: September 22, 2015; Revised received: June 17, 2016; Accepted: August 12, 2016

\begin{abstract}
The experiment was undertaken to study the influence of different growth regulators on seed yield and seed quality parameters in ridge gourd [Luffa acutangula (Roxb) L.]. There were 30 treatment combinations comprising of two factors; plant growth stage as main plot treatment, and plant growth regulators as sub plot treatment embedded in a split plot design. The results indicated that significantly the highest average fruit weight $(32.76 \mathrm{~g})$, matured fruit yield per plant $(65.84 \mathrm{~g}), 100$ seed weight $(13.41 \mathrm{~g})$ and seed yield per plant $(12.79 \mathrm{~g})$ was recorded with spraying of $500 \mathrm{ppm}$ ethereal, whereas significantly the maximum fruit length $(20.89 \mathrm{~cm})$ and fruit diameter $(5.15$ $\mathrm{cm})$ with $25 \mathrm{ppm} \mathrm{GA}$. Significantly the highest seed germination $(69.22 \%)$ was recorded with spraying of $250 \mathrm{ppm}$ ethereal, while application of NAA at $50 \mathrm{ppm}$ recorded significantly the highest vigour index I (2737.85) and vigour index II (5029.33). Spraying of PGR at two to four leaf stage recorded the higher fruit length $(20.19 \mathrm{~cm})$, fruit yield per plant $(47.49 \mathrm{~g}), 100$ seed weight $(13.18 \mathrm{~g})$ and seed yield per plant $(11.98 \mathrm{~g})$ as well as highest germination (60.90\%), vigour index I (2460.80) and vigour index II (4377.66). It is concluded that spraying of 500 ppm etherel at two to four leaf stage increased the higher fruit length, fruit yield per plant, 100 seed weight and seed yield per plant as well as highest germination, vigour index I and vigour index II.
\end{abstract}

Keywords: Growth stages, Growth regulators, Ridge gourd

\section{INTRODUCTION}

The effect of growth regulator varies with plant species, variety, their growth stage, concentration of chemicals, application method and frequency of application. Growth retardant like ethrel is the substance that slows down the cell division and cell elongation in meristamatic tissue of shoot and regulates the plant height without change in the morphology and physiology of the plant (Hilli et al.,2010).

Seed is the basic and cheapest input among other inputs viz., manures, fertilizer, pesticides fungicides etc. Use of high quality seed imparts higher yield and better quality produce. The production of genetically pure seed material and to preserve its quality from harvest to next planting season is very much essential. In a seed crop, use of growth regulators and stages of spray plays a very important role for development of plant and seed. They are known to modify the sex expression, the source-sink relationship and increase the translocation of synthates effectively resulting in increased seed yield and quality (Hilli et al. 2008).

Ridge gourd belonging to a family Cucurbitacea, is gaining commercial importance as green vegetable crop. There is a great potential to increase the seed yield with good quality parameters either by reducing flower drop or by increasing fruit set. To achieve this, plant growth regulators are considered as a new gen- eration agro chemicals after fertilizers, pesticides and herbicides. Plant growth regulators have potential ability to increase the productivity of seed crop. The growth regulators such as gibbrellic acid stimulates the cell elongation of main shoot and roots, while ethrel induce maximum number of fruits, fruit length and ultimately seed yield in ridge gourd. It is quite apparent that no seed production techniques like spraying of proper growth regulators and standardized stages of spray on growth, fruit set and seed yield especially in ridge gourd is not available (Hilli et al. 2008). Hence, the present investigation was planned to develop a suitable seed production technology with growth regulator and stages of spray on seed yield and seed quality parameters of ridge gourd.

\section{MATERIALS AND METHODS}

A field experiment was conducted during summer 2013 at the Instructional Farm, Junagadh Agricultural University, Junagadh, Gujarat, India, whereas seed quality parameters from the seed produced in the field experiment were measured in the laboratory of Department of Seed Science and Technology, College of Agriculture JAU, Junagadh. There were 30 treatment combinations comprising of two factors; plant growth stage $\left(M_{1}=\right.$ Two to four leaf stage, $M_{2}=$ Flower initiation stage and $\mathrm{M}_{3}=$ Fifteen days after flower initiation 
stage) as main plot treatment, and plant growth regulators $\left(\mathrm{S}_{1}=25 \mathrm{ppm} \mathrm{GA}, \mathrm{S}_{2}=50 \mathrm{ppm} \mathrm{GA}, \mathrm{S}_{3}=250 \mathrm{ppm}\right.$ Ethrel, $S_{4}=500$ ppm Ethrel, $S_{5}=50$ ppm NAA; $S_{6}=$ 100 ppm NAA, $S_{7}=100 p p m$ Cycocel, $S_{8}=200$ ppm Cycocel, $\mathrm{S}_{9}=$ Water Spray and $\mathrm{S}_{10}=$ Control (No Spray)) as sub plot treatment embedded in a split plot design with three replication. The observations on different quantitative characters viz., average fruit weight, fruit length, fruit diameter, mature fruit yield per plant, number of seed per fruit, 100 seed weight and seed yield per plant in the field were recorded in the field, whereas seed quality parameters, viz., germination percentage (ISTA, 1993) and vigour index I and vigour index II (Abdul Baki and Anderson, 1973) were measured in the laboratory. The analysis of the field observations (seed yield and its components) were performed following split plot design, whereas seed quality parameters were analyzed following factorial completely randomized design as suggested by Steel and Torrie (1980).

\section{RESULTS AND DISCUSSION}

Effect of plant growth regulators and stages of spray on seed yield and seed quality parameters of ridge gourd is presented in Table 1 . Significantly the maximum average fruit weight was recorded in $500 \mathrm{ppm}$ etherel $\mathrm{S}_{4}$ treatment (32.76 g) and it was at par with 50 ppm NAA $S_{5}(29.80 \mathrm{~g})$. Significantly the minimum average fruit weight was recorded in $S_{9}$ treatment $(19.00 \mathrm{~g})$. The result are agreed with Kumar and Rao (1988) who reported that fruit weight was significantly increased by ethereal. Hilli (2005) recorded the highest fruit weight with spraying of ethrel and NAA in ridge gourd. Significantly the maximum fruit length was recorded in $S_{1}$ treatment $(20.89 \mathrm{~cm})$ and it was at par with $S_{10}(20.27 \mathrm{~cm}), S_{2}(20.60 \mathrm{~cm}), S_{3}(19.62 \mathrm{~cm})$, $\mathrm{S}_{4}(19.56 \mathrm{~cm}), \mathrm{S}_{6}(19.29 \mathrm{~cm})$ and $\mathrm{S}_{5}(18.80 \mathrm{~cm})$. Significantly the minimum fruit length was recorded in $S_{7}$ $(18.22 \mathrm{~cm})$ treatment. Hilli (2005) reported increased in fruit length with $\mathrm{GA}_{3}$ and etherel. Singh and Choudhury (1989) reported that application of $\mathrm{GA}_{3}$ increased fruit length and Arora et al. (1987) reported maximum fruit length with etherel in ridge gourd. Dostogir et al. (2006) and Ghani et al. (2013) also reported similar finding that fruit length was increased with spraying of $\mathrm{GA}_{3}$ in bitter gourd. The $\mathrm{S}_{1}$ treatment $(5.15 \mathrm{~cm})$ manifested significantly the higher fruit diameters and it was at par with $S_{10}(4.42 \mathrm{~cm})$ and $S_{3}(4.36 \mathrm{~cm})$. The $S_{5}$ $(3.93 \mathrm{~cm})$ treatment gave significantly minimum fruit diameter. This finding are in conformity with the Singh and Choudhury (1989) and Hilli (2005), who reported that fruit diameter were increased with spraying of etherel in ridge gourd; and similarly Dostogir et al. (2006) and Ghani et al. (2013) also recoeded the same results in bitter gourd. Significantly the higher matured fruit yield per plant was recorded with etherel in $\mathrm{S}_{4}$ treatment $(65.84 \mathrm{~g})$. Significantly the minimum mature fruit yield per plant was recorded in $S_{10}$ treat-

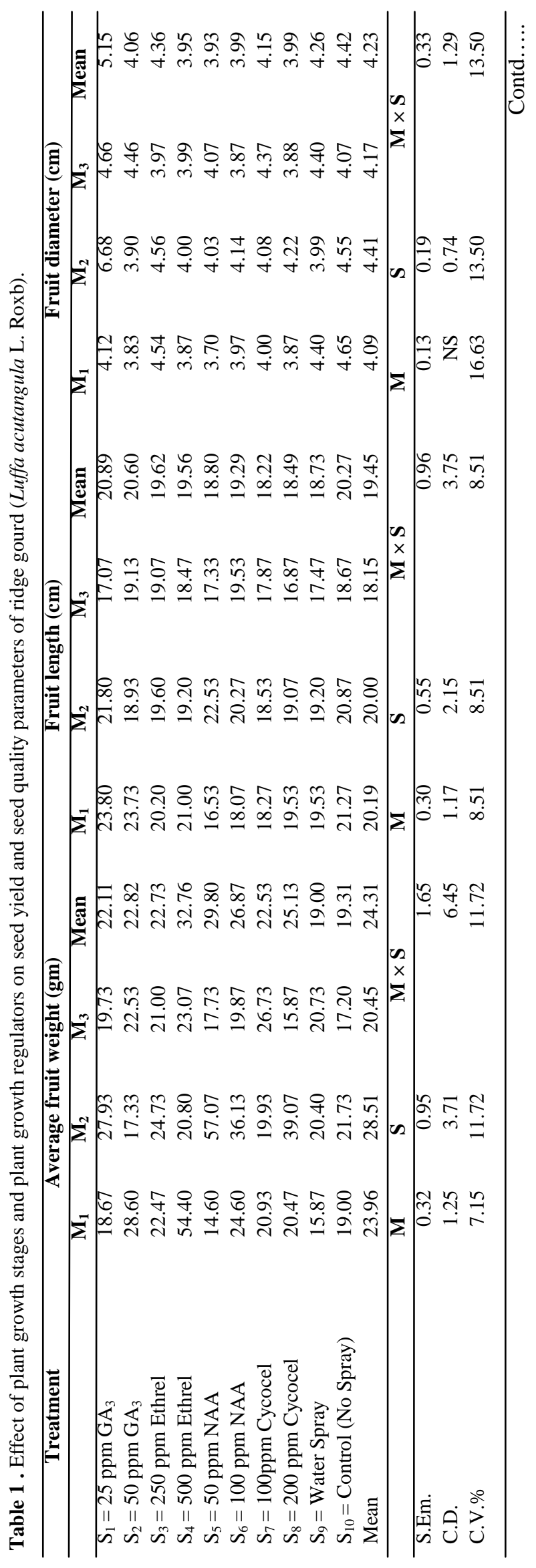


Sondarva Jyoti et al. / J. Appl. \& Nat. Sci. 8 (3): 1551 - 1555 (2016)

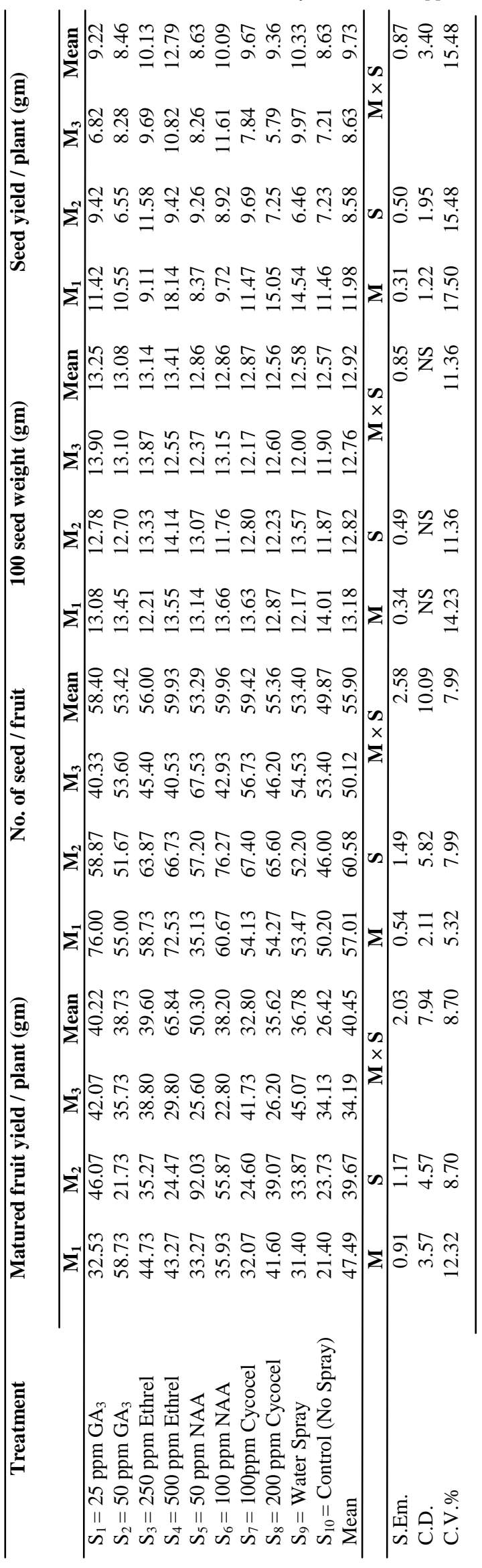

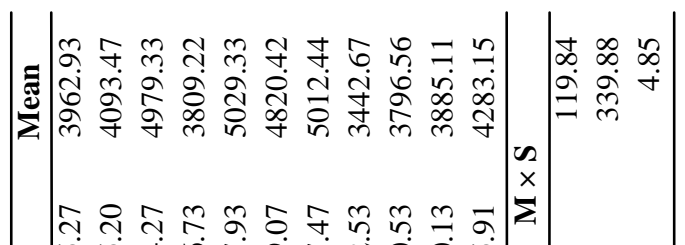

$=\Rightarrow \mid \begin{array}{lll}0 \\ 0\end{array}$

密

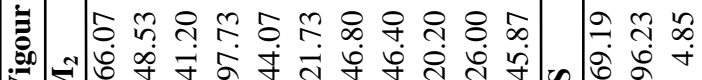

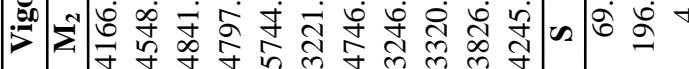

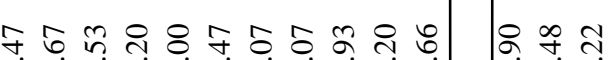

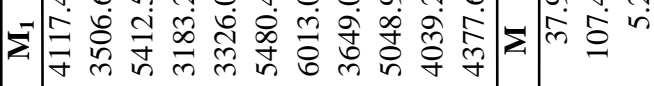

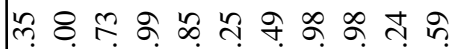

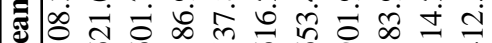

ㅇํㅇำ

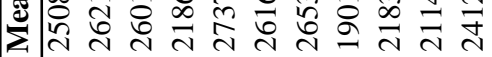

$\dot{\infty} \dot{\infty}+$

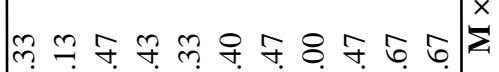

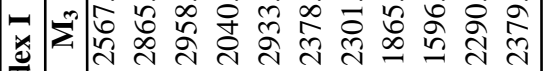

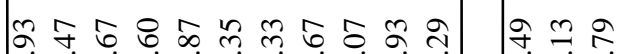

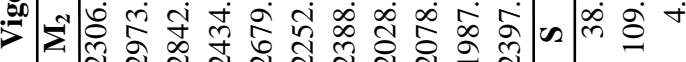

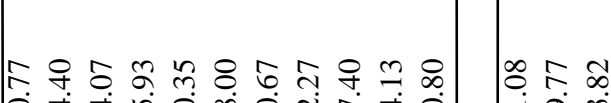

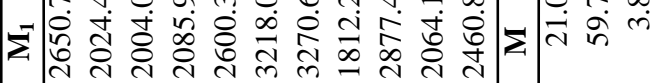

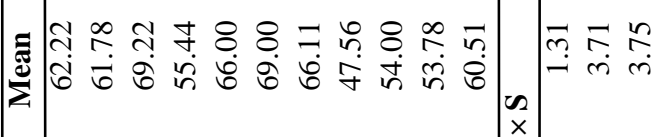

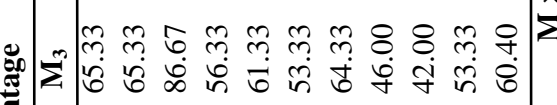

טُّ

స 8 \& 8 m \&

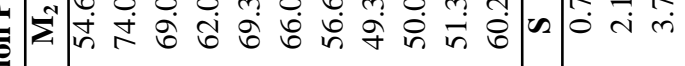

ธ \& \& \&

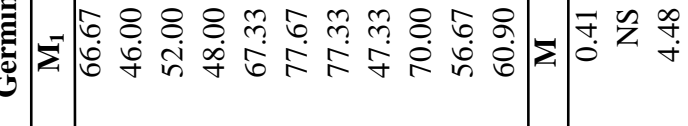


ment (26.42 g). Similar results were also obtained by Arora et al. (1987), Kumar and Rao (1988), Singh and Choudhury (1989) and Hilli (2005), who reported that the mature fruit yield was increased with spraying of etherel in ridge gourd. Jadav et al. (2010) and Thappa et al. (2011) also recorded the same results in cucumber. Baset et al. (2014) reported that fruit yield was increased with etherel in bitter gourd. Significantly the highest number of seed per fruit was recorded in $\mathrm{S}_{6}$ treatment (59.96) and it was at par with $S_{4}$ (59.93), $S_{7}$ (59.42), $S_{1}(58.40), S_{3}(56.00)$ and $S_{8}$ (55.36). Significantly the lowest number of seed per fruit was recorded in $S_{10}$ treatment (49.87). The findings were in accordance with Hilli (2005), who reported significantly the highest number of seed per fruit with application of NAA in ridge gourd, similarly, Gedam et al. (1996); Gedam et al. (1998) and Marbhal et al. (2005), who also reported the same results in bitter gourd. Significantly the highest 100 seed weight was recorded in $\mathrm{S}_{4}$ treatment $(13.41 \mathrm{~g})$ followed by $\mathrm{S}_{1}(13.25 \mathrm{~g})$. The minimum 100 seed weight was observed in $S_{8}$ treatment $(12.56 \mathrm{~g})$. This finding were conformed by Hilli (2005), who recorded the highest 100 seed weight with the application of etherel in ridge gourd, and same results was also reporded by Gedam et al. (1996) in bitter gourd and Ram et al. (1988) in cucumber. The $\mathrm{S}_{4}$ treatment $(12.79 \mathrm{~g})$ noted significantly the highest seed yield per plant than all treatments. The $S_{2}$ treatment $(8.46 \mathrm{~g})$ produced the minimum seed yield per plant. Results in accordance with the results of Hilli et al. (2010), who recorded the highest seed yield per plant with all the treatments in ridge gourd. Similar results were also reported by Marbhal et al. (2005) and Shantappa et al. (2007) in bitter gourd.

Significantly the highest seed germination was recorded in $\mathrm{S}_{3}$ treatment $(69.22 \%)$ and it was at par with S6 $(69.00 \%)$. The significantly minimum seed germination was observed in $\mathrm{S}_{8}$ treatment $(47.56 \%)$. The results are similar to the findings reported by Hilli (2005), Hilli et al. (2008) and Hilli et al. (2010), who recorded the highest germination with etherel in ridge gourd. Same finding are conformed by Gedam et al. (1996) and Shantappa et al. (2007) with application of etherel in bitter gourd. The application of NAA at 50 ppm $\left(S_{5}\right.$ treatment) recorded significantly the highest vigour index I (2737.85) and vigour index II (5029.33) and it was at par with $\mathrm{S}_{7}$ (2653.49 and 4979.33, respectively). The present findings are in conformity with Hilli (2005) and Hilli et al. (2008), who recorded highest vigour index I and vigour index II with application of NAA in ridge gourd and Shantappa et al. (2007) in bitter gourd. Significantly the lowest vigour index I and vigour index II was observed in $\mathrm{S}_{8}$ treatment with a value of 1901.98 and 3442.67 in that order.

Spraying of plant growth regulators at flower initiation stage recorded the maximum fruit weight $(28.51 \mathrm{~g})$, fruit diameter $(4.41 \mathrm{~cm})$ and number of seed per fruit
(60.58). These results are in agreement with the results of Hilli (2005) and Hilli et al. (2008) who observed maximum fruit weight, fruit diameter and number of seed per fruit with application of plant growth regulators at flower initiation stage in ridge gourd. Similar results are conformed by Ghani et al. (2013) in bitter gourd, Spraying of plant growth regulators at two to four leaf stage recorded the higher fruit length (20.19 $\mathrm{cm}$ ), fruit yield per plant (47.49 g), 100 seed weight $(13.18 \mathrm{~g})$ and seed yield per plant $(11.98 \mathrm{~g})$. The findings are similar as reported by Hilli et al. (2010) in ridge gourd; and Shantappaa et al. (2007) and Ghani et al. (2013) in bitter gourd.

Spraying of growth regulators at two to four leaf stage recorded highest germination $(60.90 \%)$, vigour index I (2460.80) and vigour index II (4377.66). The present findings are in conformity with Hilli (2005) and Hilli et al. (2008) who recorded the highest seed germination, vigour index I and vigour index II were application of plant growth regulators at two to four leaf stage in ridge gourd.

\section{Conclusion}

From the results, it can be concluded that spraying of $500 \mathrm{ppm}$ ethrel is recommended to increase the average fruit weight $(32.76 \mathrm{~g})$, matured fruit yield per plant $(65.84 \mathrm{~g}), 100$ seed weight $(13.41 \mathrm{~g})$ and seed yield per plant $(12.79 \mathrm{~g})$ in ridge gourd. However, spraying of 25 ppm $\mathrm{GA}_{3}$ increased the fruit length $(20.89 \mathrm{~cm})$ and fruit diameter $(4.42 \mathrm{~cm})$, whereas spraying of $250 \mathrm{ppm}$ etherl is recommended for increasing germination percentage $(69.22 \%)$ and 50 ppm NAA for vigour index I (2737.85) and vgour index II (5029.33). Spraying of plant growth regulator at two to four leaf stage is recommended to increase the higher fruit length (20.89 $\mathrm{cm})$, fruit yield per plant $(65.84 \mathrm{~g}), 100$ seed weight $(13.41 \mathrm{~g})$ and seed yield per plant $(11.98 \mathrm{~g})$ as well as highest germination $(69.22 \%)$, vigour index I (2737.85) and vigour index II (5029.33).

\section{REFERENCES}

Abdul Baki, A. A. and Anderson, J. D. (1973). Vigor determinations in soybean seed multiple criteria. Crop Sci., 13: 630-633.

ISTA (1993). International Rules for Seed Testing. International Seed Testing Association Seed Sci. technol., 21: 1-288.

Arora, S. K.; Pandita, M. L. and Dahiya, M. S. 1987. Effect of plant growth regulators on vegetative growth, flowering and yield of ridge gourd (Luffa acutangula Roxb.). Haryana Agric. Univ. J. Res., 27(4): 319-324.

Baset, M. A.; Islam S.; Miah Y.; Das M. R. and Khan H. I. (2014). Flower synchrony, growth and yield enhancement of small type bitter gourd (Momordica charantia L.) through plant growth regulators and NPK fertilization. Pak. J. Biological Sci., 17: 408-413.

Dostogir, H.; Abdul Karim, M.; Habibur Rahman Pramanik, M.; Syedur Rahman, A. A. M. 2006. Effect of gibberel- 
lic acid $\left(\mathrm{GA}_{3}\right)$ on flowering and fruit development of bitter gourd (Momordica charantia L.). Intl. J. Bot., 2 (3): 329-332.

Gedam, V. M., Patil, R. B., Suryawanshi, Y. B. and Mate, S. N. 1996.Seed quality as influenced by plant growth regulators in bitter gourd. Seed Res., 24(2): 158-159.

Gedam, V. M.; Patil, R. B.; Suryawanshi, Y. B. and Mate, S. N. 1998. Effect of plant growth regulators and boron flowering, fruiting and Seed yield in bitter gourd. Seed Res., 26(1): 97-100.

Ghani, M. A.; Amjad, M.; Iqbal, Q.; Nawaz, A.; Ahmad, T.; Abdul Hafeez, O. and Abbas, M. 2013. Efficacy of plant growth regulators on sex expression, earliness and yield components in bitter gourd. Pak. J. Life Soc. Sci., 11(3): 218-224.

Hilli, J. S. 2005. Studies on seed production and post-harvest techniques in ridge gourd (Luffa acutangulaL. Roxb). $\mathrm{Ph}$. D. Thesis (unpublished). University of Agricultural Sciences, Dharwad.

Hilli, J. S.; Vyakarnahal, B. S. and Patil, S. S. 2008. Influence of growth regulators and stages of spray on sex expression of ridge gourd. Karnataka J. Agric. Sci., 21 (2): 198-201.

Hilli, J. S.; Vyakarnahal, B. S.; Biradar, D. P. and Hunje, R. 2010. Effect of growth regulators and stages of spray on growth, fruit set and seed yield of ridge gourd. Karnataka J. Agric. Sci., 23(2): 239-242.

Jadav, R. G.; Patel, T. V.; Parmar, A. B. and Saiyad, M. Y. 2010. Sex modification of cucumber vegetable through
PGRs. J. Pure and App. Sci., 18: 13 - 14.

Kumar, B. S. and Rao, M. R. 1988. Effect of certain plant growth regulators and nutrients on growth, sex expression and yield of ridge gourd.South Indian Hort., 36(6): 336-339.

Marbhal, S. K.; Musmade, A. M.; Kashid, N. V.; Kamble, M. S. and Kamthe, P. V. 2005. Effect of growth regulators and picking sequence on seed yield of bitter gourd. Hrayana J. Hort. Sci., 34(3-4): 323-332.

Ram, S.; Habib, A. F. and Rudraradhya, M. 1988. Effect of plant growth regulators and dates of sowing on sex expression with special reference to seed production in Cucumis Sativus L. variety Pickling Ham. Seeds and Farms, 14(1-3): 20-24.

Shantappa, T.; Shekhargouda, M.; Merwade, M. N. and Deshpande, V. K. 2007. Seed yield and quality as influenced by plant growth regulators and stage of spray in bitter gourd. Seed Res., 35(1): 11-16.

Singh, R. K. and Choudhury, B. 1989. Differential responses of three genera of cucurbits to boron and plant growth regulators. Indian J. Hort., 46: 215-221.

Thappa, M.; Kumar, S. and Rafiq, R. 2011. Influence of plant growth regulators on morphological, floral and yield traits of cucumber (Cucumis sativus L.). Kasetsart J. (Nat. Sci.), 45: 177-188.

Steel, R. G. D. and Torrie, J. H. (1980). Principles and Procedures of Statistics, Second Edition, McGraw-Hill Book Co., New York. 